\title{
Investigations of Gas-Phase Lithium-Peptide Adducts: Tandem Mass Spectrometry and Semiempirical Studies
}

\author{
Julie A. Leary, Zhongrui Zhou, Sherri A. Ogden, and Todd D. Williams \\ College of Chemistry, University of California, Berkeley, California, USA
}

\begin{abstract}
Tandem mass spectrometry using a hybrid mass spectrometer of BEqQ geometry was used to investigate the gas-phase formation of the $\left[\mathrm{A}_{n}+\mathrm{Li}-\mathrm{H}\right]^{+}$ion from lithium-peptide adducts. High resolution mass measurements as well as precursor and product ion scans of five peptides indicate that one source of $\left[\mathrm{A}_{n}+\mathrm{Li}-\mathrm{H}\right]^{+}$arises from $\left[\mathrm{A}_{n}+\mathrm{Li}\right]^{+}$. Semiempirical calculations (MNDO) and metastable ion decomposition studies of the peptide Gly-Gly-Gly show that the lithium ion prefers to condinate to the three internal carbonyls of the neutral molecule to give a species that is energetically more stable than the lithiated zwitterion by $305 \mathrm{~kJ} / \mathrm{mol}$. Theoretical and experimental evidence suggest that the monolithiated precursor ion population may be a distribution of structural isomers. (I Am Soc Mass Spectrom 1990, 1, 473-480)
\end{abstract}

$\mathrm{T}$ The mechanism of formation of sequence specific product ions generated from alkali metal-peptide adducts has been the subject of much interest [1-6]. Structures have been postulated and mechanisms formulated for the formation of the $\left[\mathrm{B}_{\mathrm{n}}+\mathrm{O}+\right.$ Metal $+\mathrm{H}^{+}$ions obtained from collision-induced dissociation (CID) or metastable decomposition (MD) of $[\mathrm{M}+\mathrm{Na}]^{+}[1,3]$ and $[\mathrm{M}+\mathrm{Li}]^{+}[4,5]$ precursor ions. These $B_{n}$ ions have become important for determining the sequential loss of C-terminal amino acids from these adduct ions. Similarly, a key ion for determining the N-terminal amino acid sequence is the $\left[\mathrm{A}_{\mathrm{n}}+\text { Metal }-\mathrm{H}\right]^{+}$ion observed from CID or MD of $\left[\mathrm{M}+\mathrm{Li}^{+}[4,5],[\mathrm{M}+2 \mathrm{Li}-\mathrm{H}]^{+}[5],[\mathrm{M}+\mathrm{Na}]^{+}\right.$ $[1,6]$, and $[\mathrm{M}+2 \mathrm{Na}-\mathrm{H}]^{+}[1]$ precursors.

At least two different mechanisms have been proposed for the $\left[\mathrm{A}_{\mathrm{n}}+\mathrm{Li}-\mathrm{H}\right]^{+}$ion formation $[4,5]$, and much of the data presented here regard the formation of this specific ion. The goal is not necessarily to negate the existence of one mechanism but to show that others are also responsible for the formation of this ion and that this may be in part due to structurally different precursors. More generally, however, part of the aim of this work is to suggest through theoretical calculations and experimental results that different structural forms of metal-cationized (or more specifically lithium-cationized) peptides exist in the gas phase and that some of these structures differ by only a few kilocalories. This makes assigning

Address reprint requests to Julie A. Leary, College of Chemistry, University of California, Berkeley, CA 94720 . mechanisms very difficult. It also suggests that what may be true for one peptide (or class of peptides) and one metal is probably not true for another. The nature of the amino acid side chain, length of the peptide, the number of internal carbonyls, and the number of acidic residues are only some of the structural features that dictate how a metal may coordinate.

In this study, low energy CID experiments were carried out using a tandem hybrid mass spectrometer of $\mathrm{BEqQ}$ geometry. Five lithiated, deuterated peptides were examined. Parent (hereafter referred to as precursor) ion scans as well as daughter (hereafter referred to as product) ion scans were obtained to ascertain how the $\left[\mathrm{A}_{\mathrm{n}}+\mathrm{Li}-\mathrm{H}\right]^{+}$ion is formed. In addition, high resolution mass measurements were made to assign accurately some of the ions in question. Semiempirical calculations and metastable ion scan experiments were carried out on one small peptide in order to obtain theoretical and experimental results in support of an energetically stable lithium-cationized molecular species. This latter experiment raises new questions on the mechanisms of formation of the $\left[\mathrm{B}_{\mathrm{n}}+\mathrm{OLi}+\mathrm{H}\right]^{+}$ion.

\section{Experimental}

Mass spectra were obtained using a VG ZAB2-EQ mass spectrometer of BEqQ geometry (VG Analytical Ltd, Greater Manchester, UK). Fast atom bombardment (FAB) mass spectrometry experiments were performed using a cesium ion gun operated at $20 \mathrm{kV}$ and $1.0 \mu \mathrm{A}$ emission current. The accelerating voltage was $8 \mathrm{kV}$ and the mass range from 100 to $1000 \mathrm{u}$ was scanned at $15 \mathrm{sec} /$ decade. 


\section{Collision-Induced Dissociation}

Product ion spectra were generated from CID of the monolithiated and dilithiated molecular ions transmitted into the rf only quadrupole (q) with $15-20 \mathrm{eV}$ collision energy (laburatury frame-of-reference). Argon gas pressure $\left(1-2 \times 10^{-6}\right.$ Torr $)$ was measured with an ion gauge near the quadrupole collision cell. Low energy CID spectra were abtained by scanning the mass analyzer up in mass from $40-700 u$ in $10-15$ seconds and five to ten scans were acquired under data system control in the MCA (multichannel analyzer) mode. The mass scale of the quadrupole analyzer $(Q)$ was calibrated using low and high mass ions obtained from CID of the protonated molecule PheLeu-Glu-Glu-Ile [5] (Sigma Chemical Co., St. Louis, $\mathrm{MO}$ ), or from the cluster ions of glycerol.

Precursor ion spectra were generated by scanning the magnet (B) while setting $Q$ to pass only the mass of the product ion. This type of scan was again acquired under data system control with the mass range of 50-700 u used for the front end scan.

\section{Metastable Ion Scans}

Metastable product ion spectra were collected in the same manner as CID product ion spectra with the exception that collision gas was not used in these experiments. Pressure in $\mathrm{q}$ was between $10^{8}$ and $10^{-9}$ Torr. Precursor ions thus underwent unimolecular decompositions resulting in ions that were mass analyzed in $\mathrm{Q}$.

\section{High Resolution Mass Measurements}

Accurate mass measurements were made at 1:20,000 resolution by peak matching the source-derived peptide ions of $\mathrm{m} / \mathrm{z} 416$ and 402 of the lithiated peptide YAGFM and YGGFL, respectively, against the protonated molecule tryptophyl-tryptophan $(\mathrm{m} / z 391.1770)$ (Sigma Chemical Co).

\section{Samples}

Five peptides were used for the labeling experiments. These included: leucine-enkephalin (YGGFL), [D$\mathrm{Ala}^{2}$ ] methionine-enkephalin (YAGFM), $\beta$ casomorphin fragment 1-5 (YPFPG), glycyl-glycylglycine (GGG), and alanyl-alanyl-alanyl-alanyl-alanine (AAAAA), (Sigma Chemical Co). Deuterated peptides were prepared by lyophilizing $2 \mathbf{~ m g}$ of peptide four times with $500 \mu \mathrm{L}$ aliquots of $\mathrm{D}_{2} \mathrm{O}(99.9 \% \mathrm{D}$, Cambridge Isotope Laboratories, Woburn, MA). The final lyophilization was taken to $100 \mu \mathrm{L}$ in $\mathrm{D}_{2} \mathrm{O}$, and this was used as the stock solution for all experiments. Samples for mass spectrometry of the deuterated peptide were diluted 1:1 with $\mathrm{D}_{3}$-glycerol (ICN Biomedicals Inc., Cambridge, $M A$ ) or $\mathrm{D}_{4}$-dithiothreitol/ $\mathrm{D}_{4}$-dithioerythritol (3:1 mixture prepared in our laboratory) and $1 \mu \mathrm{L}$ applied to the stainless steel probe tip. Samples for CID experiments on the deuteriumlabeled monolithiated precursor were prepared by mixing the $1: 1$ solution described above with $0.23 \mathrm{M}$ ${ }^{6} \mathrm{LiOD}$ in a 5:2 (peptide: ${ }^{6} \mathrm{LiOD}$ ) ratio. For collision experiments on the dilithiated precursor, the ratio was $1: 2$ (peptide: ${ }^{6} \mathrm{LiOD}$ ).

\section{Semiempirical Calculations}

Modified neglect of differential overlap (MNDO) calculations [7] were performed using a general purpose semiempirical molecular orbital package (MOPAC) written by James J. P. Stewart (Frank J. Seiler Research Lab, USAF Academy, Colorado Spring, CO). The semiempirical Hamiltonian MNDO is used in the electronic part of the calculation to obtain molecular orbitals, ionization potentials, and the heats of formation. In principle the user creates a data file that describes a molecular system and specifies what kind of calculations and output are desired. MOPAC runs from a computer aided chemistry (CAChe) worksystem that is a combination of hardware and software developed for the Macintosh by Tektronix.

The cartesian coordinates for Gly-Gly-Gly [8] were entered into the MOPAC input file from which a three-dimensional structure was drawn and exhibited on the Tektronix 3-D system. Lithium was added to various sites on the molecule, and dihedral angles were altered in order that possible logical variations of the molecule conformation could be calculated. As the program proceeds, the calculation minimizes the structure to its most energetically stable form given the data input. For example, for Gly-Gly-Gly in a total trans orientation, lithium was initially placed immediately adjacent to one of the carboxylate oxygens and the $\mathrm{N}$-terminus was designated as $\mathrm{NH}_{3}^{+}$. The calculation, however, minimized this to give a more energetically favorable structure that places the lithium equidistant between the two oxygens of the carboxylate (see Results for structures obtained). For this particular structure only the total trans configuration was entered into the program. This was based on evidence showing both neutral and zwitterionic peptides to be most stable with the peptide bond in the trans orientation [9].

\section{Results and Discussion}

Previous work has shown that the $\left[\mathrm{A}_{n}+\mathrm{Li}-\mathrm{H}\right]^{+}$ ion is present in the CID spectra from both monolithiated $[4,5]$ and dilithiated [5] precursor ions. As depicted in Schemes I and II, this ion could appear as $m / z 421$ or 422 for the deuterated lithiated salt of YAGFM depending on the mechanism of formation. Grese et al. [4] suggested that in the case of monolithiated peptides, this ion is formed via Scheme I, whereby a lithium rearrangement occurs from the C-terminal carboxylate salt in which deuterium is dis- 


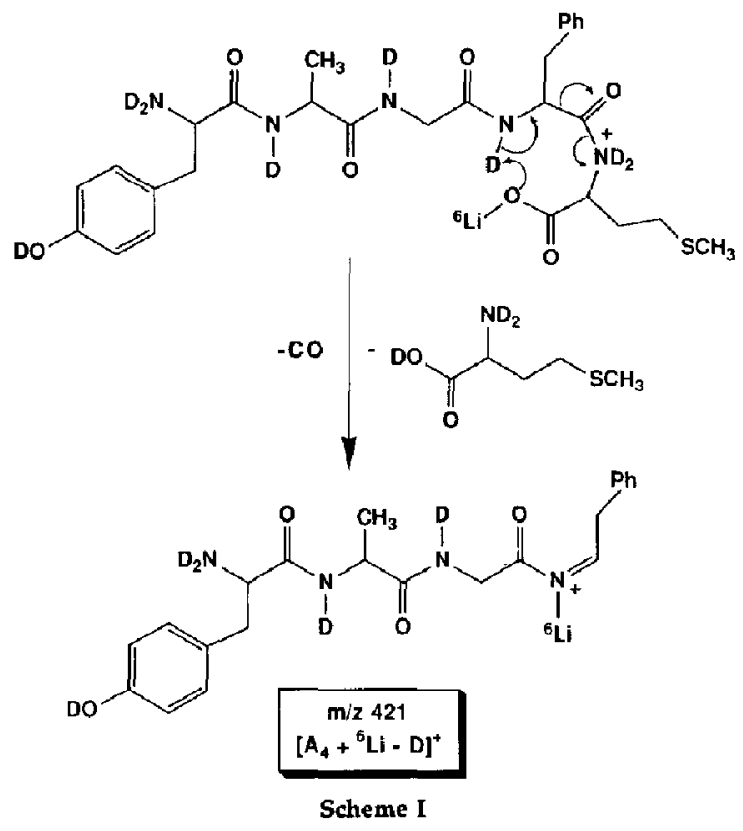

placed by lithium and, after neutral losses, the $\left[A_{n}+\right.$ $\mathrm{Li}-\mathrm{D}]^{+}$ion is formed. We proposed earlier that this ion is formed by Scheme II [5]. In this case $\left[\mathrm{A}_{\mathrm{n}}+\mathrm{Li}\right]^{+}$ is formed from which a hydrogen radical is lost from the beta carbon of the phenylalanine side chain thus<smiles>[2H]N(C(=O)CN([2H])c1ccccc1)C(=O)C(C)N([2H])C(=O)C(Cc1ccc([O-])cc1)[N+](=O)[O-]</smiles><smiles>CC(C)C</smiles><smiles>[2H]N(CC(=O)N([2H])/C(=C\C[18F])c1ccccc1)C(=O)C(C)N([2H])C(=O)C(Cc1ccc(O)cc1)N=O</smiles>

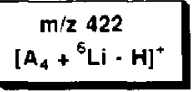

Scheme II
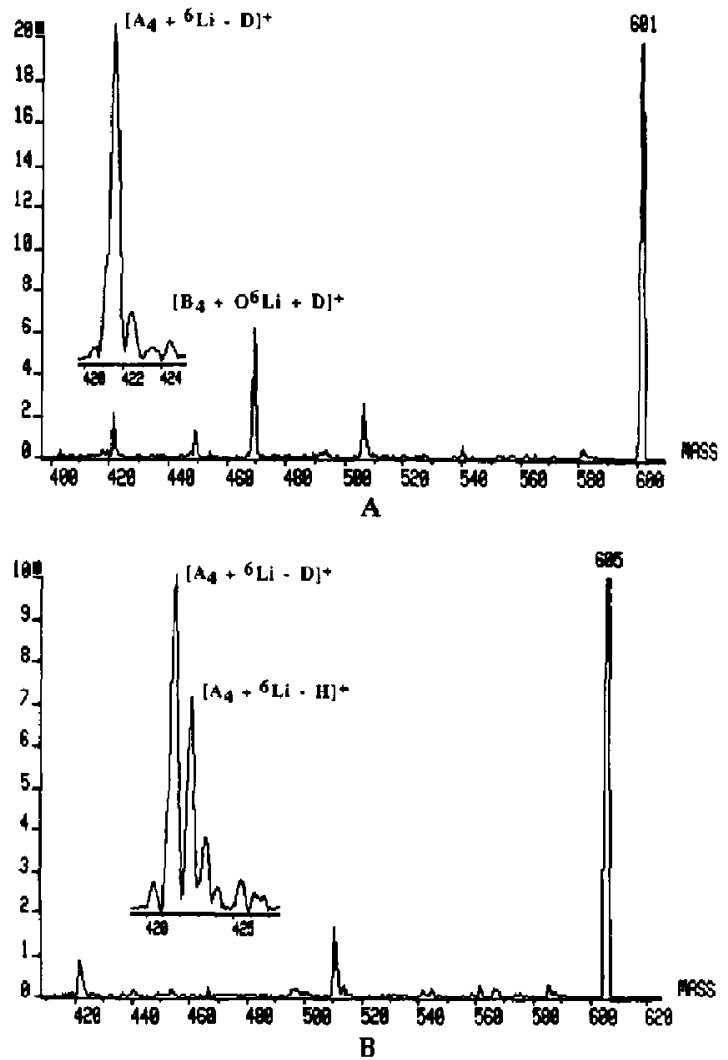

Figure 1. (a) Partial CID spectrum of $\left[M+{ }^{6} \mathbf{L i}\right]^{+}$from deuterated YAGFM. (b) Partial CID spectrum of $\left[\mathrm{M}+2^{6} \mathrm{Li}-\mathrm{D}\right]^{+}$ from deuterated YAGFM.

affording an $\left[\mathrm{A}_{n}+\mathrm{Li}-\mathrm{H}\right]^{+}$ion. The analogous $\mathrm{A}_{n}$ ion formed from protonated peptides has been proposed to arise by the mechanism shown in Scheme II via CID of the $\left[A_{5}+1\right]$ ion of Substance $P[10]$.

For all experiments the isotope ${ }^{6} \mathrm{Li}$ was used in order to reduce confusion in the tandem mass spectrometry (MS/MS) spectra of both deuterated and nondeuterated peptides. Also, because of the inherent confusion of adding hydrogen, deuterium, and lithium to various fragments, sequence ions are reported with the corresponding number of lithiums or deuteriums added. For example, the ion $\mathrm{m} / \mathrm{z} 469$ in Figure 1a corresponds to the $B_{4}$ ion [11] plus one oxygen, one deuterium, and one lithium. Thus its designation is $\left[\mathrm{B}_{4}+\mathrm{O}^{6} \mathrm{Li}+\mathrm{H}\right]^{+}$. Similarly, the $\left[\mathrm{A}_{4}\right.$ $\left.{ }^{6}{ }^{6} \mathrm{Li}-\mathrm{H}\right]^{+}$ion is the $\mathrm{A}_{4}$ ion to which one lithium has been added and one hydrogen removed.

\section{Collision-Induced Dissociation of Labeled Peptides}

In order to better determine the mechanism(s) for the formation of the $\left[\mathrm{A}_{n}+{ }^{6} \mathrm{Li}-\mathrm{H}\right]^{+}$ion, labeling experiments were conducted in which all the exchangeable 
Table 1. Ratio of $\left[\mathrm{A}_{\mathrm{n}}+{ }^{6} \mathrm{Li}-\mathrm{D}\right]^{+} /\left[\mathrm{A}_{\mathrm{n}}+{ }^{6} \mathrm{Li}-\mathrm{H}\right]{ }^{+}$ion abundances relative to $\left[\mathrm{A}_{\mathrm{n}}+{ }^{6} \mathrm{Li}-\mathrm{D}\right]^{+}$ from $\mathrm{CID}$ of the monolithiated and dilithiated molecular ions of indicated peptides

\begin{tabular}{|c|c|c|c|}
\hline Peptide & Mass & $\begin{array}{l}\% \text { Abundance } \\
\text { from }\left[M+{ }^{6} \mathrm{Lj}\right]^{+}\end{array}$ & $\begin{array}{c}\% \text { Abundance } \\
\text { from }\left[M+2^{6} L i-D\right]^{+}\end{array}$ \\
\hline & \multicolumn{3}{|c|}{$\left[\Lambda_{n}+{ }^{6} \mathrm{Li}-D\right]^{+} /\left[\Lambda_{n}+{ }^{6} \mathrm{Li}-H\right]^{+}$} \\
\hline $\begin{array}{l}\text { YAGFM } \\
\left(A_{4}\right)\end{array}$ & $421 / 422$ & $100 / 15$ & $100 / 65$ \\
\hline $\begin{array}{l}\text { YPFPG } \\
\left(A_{3}\right)\end{array}$ & $389 / 390$ & $100 / 18$ & $100 / 53$ \\
\hline $\begin{array}{l}\text { YGGFL } \\
\left(\mathrm{A}_{4}\right)\end{array}$ & $407 / 408$ & $100 / 50$ & $100 / 95$ \\
\hline $\begin{array}{l}\text { AAAAA } \\
\left(\mathrm{A}_{4}\right)\end{array}$ & $266 / 267$ & $100 / 10$ & $100 / 15$ \\
\hline $\begin{array}{l}\text { GGG } \\
\left(\mathrm{A}_{2}\right)\end{array}$ & $94 / 95$ & $100 / 0$ & $100 / 0$ \\
\hline
\end{tabular}

sites on several peptides were labeled with deuterium. Table 1 lists the peptides and the relative ratios of the $\left[\mathrm{A}_{\mathrm{n}}+{ }^{6} \mathrm{Li}-\mathrm{D}\right]^{+} /\left[\mathrm{A}_{\mathrm{n}}+{ }^{6} \mathrm{Li}-\mathrm{H}\right]^{+}$ions obtained when both the monolithiated and dilithiated precursors underwent $\mathrm{CID}$. Figure $1 \mathrm{a}$ and $\mathrm{b}$ are the partial MS/MS product ion spectra in which the peptide YAGFM is exemplified. The insets of Figure 1 demonstrate that the analyzer quadrupole was tuned for unit mass resolution. The results clearly indicate that both $\left[A_{n}+{ }^{6} L i-D\right]^{+}$and $\left[A_{n}+{ }^{6} L i-H\right]^{+}$ions are formed, albeit in differing relative abundances. This suggests that more than one mechanism leads to the formation of this ion. The only peptide for which this is not the case is GGG. (This particular peptide will be discussed in detail further on.)

Interestingly, the abundance of the $\left[\mathrm{A}_{n}+{ }^{6} \mathrm{Li}-\right.$ $\mathrm{H}]^{+}$ion is always greater when the $\left[\mathrm{M}+2{ }^{6} \mathrm{Li}-\mathrm{D}\right]^{+}$ is the precursor (this is shown more dramatically in the precursor ion spectra shown later). Possible structures of the dilithiated precursor are currently under investigation. Preliminary data suggest that the site of coordination of the lithium ion enhances and/or suppresses one fragmentation pathway over another. It also appears that the nature of the side chain may influence the formation of $\left[\mathrm{A}_{\mathrm{n}}+{ }^{6} \mathrm{Li}-\mathrm{H}\right]^{+}$ion when the dilithiated molecular ion is the precursor, as evidenced by the differences in abundances, that is, loss of a hydrogen radical from the beta carbon of the phenylalanine side chain is a more facile process than said loss from the methyl group of alanine. The formation of both ions, as well as the differences observed in the abundances of these ions, suggests that one mechanism may be favored over another depending on where the lithium coordinates on the molecule. Another observation is that an ion whose mass corresponds to $\left[\mathrm{A}_{\mathrm{n}}+{ }^{6} \mathrm{Li}\right]^{+}$is seen in all the CID spectra of the $\left[\mathrm{M}+2{ }^{6} \mathrm{Li}-\mathrm{D}\right]^{+}$from the peptides investigated with the exception of GGG. In order to determine if $\left[\mathrm{A}_{\mathrm{n}}+{ }^{6} \mathrm{Li}\right]^{+}$is in fact a precursor to $\left[\mathrm{A}_{\mathrm{n}}+{ }^{6} \mathrm{Li}-\mathrm{H}\right]^{+}$ as suggested in Scheme II, precursor ion scans were collected for all the peptides analyzed, data for which are presented below.

\section{Precursor Ion Scans}

Unlike the product ion scans, precursor scans were obtained from the protiated and lithiated peptides. As we are primarily interested in determining if one possible mechanism for the formation of $\left[\mathrm{A}_{\mathrm{n}}+{ }^{6} \mathrm{Li}-\right.$ $\mathrm{H}]^{+}$is from $\left[\mathrm{A}_{\mathrm{n}}+{ }^{6} \mathrm{Li}\right]^{+}$, deuteration of the peptides was not essential. Figure $2 a$ and $b$ are the precursor ion scans for the $\left[\mathrm{A}_{4}+{ }^{6} \mathrm{Li}-\mathrm{H}\right]^{+}$and $\left[\mathrm{A}_{3}+{ }^{6} \mathrm{Li}-\right.$
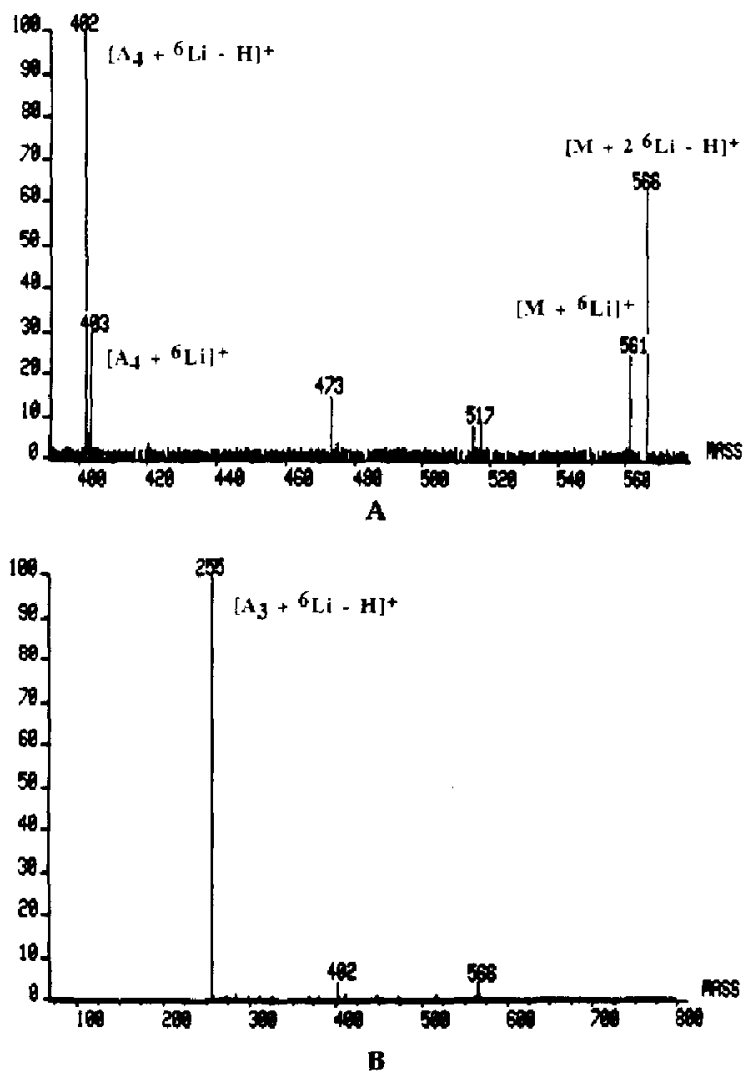

Figure 2. (a) Precursor ion scan of $\left[\mathrm{A}_{4}+{ }^{6} \mathrm{Li}-\mathrm{H}\right]^{+}$from $\mathrm{YG}-$ GFL. (b) Precursor ion scan of $\left[\mathrm{A}_{3}+{ }^{6} \mathrm{Li}-\mathrm{H}\right]^{+}$from YGGFL. 


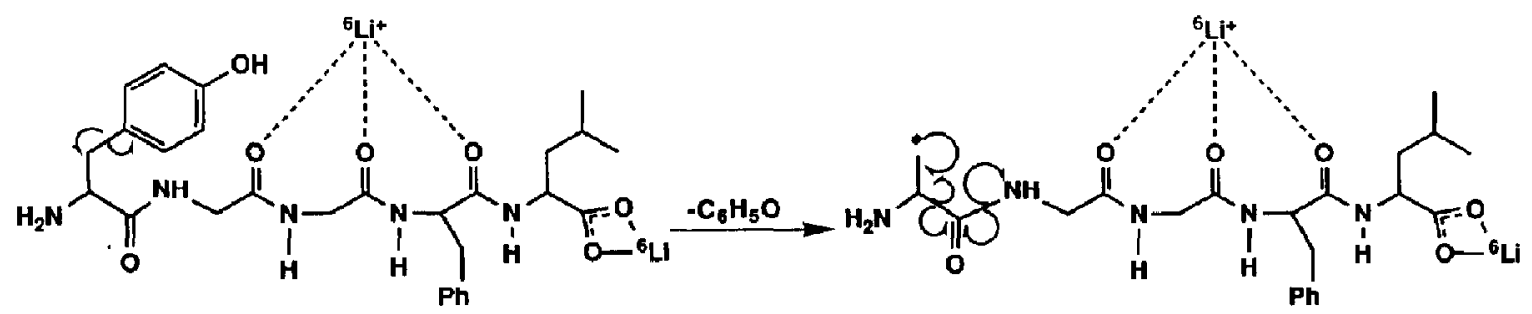

$m / 2 \quad 566$

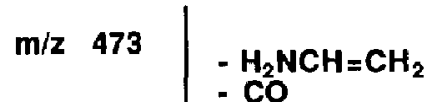<smiles>CC(C)CC(NC(=O)C(Cc1ccccc1)NC(=O)NC(CN)CN)C(=O)O[Ga]</smiles>

$\mathrm{m} / \mathrm{z} \quad 402.2206$

$\mathrm{C}_{19} \mathrm{H}_{26} \mathrm{~N}_{4} \mathrm{O}_{5}{ }^{6} \mathrm{Li}_{2}$

Scheme III

$\mathrm{H}^{+}$ions, respectively, of YGGFL. As shown in a, the $\left[\mathrm{A}_{4}+{ }^{6} \mathrm{Li}-\mathrm{H}\right]^{+}$ion appears to arise not only from the monolithiated and dilithiated precursors, but from several other ions, one of which is $m / z 403$ and presumably the $\left[\mathrm{A}_{4}+{ }^{6} \mathrm{Li}\right]^{+}$ion. Seen here, as in the product ion spectrum (Figure $1 \mathrm{~b}$ ), the dilithiated molecular ion appears to be more of a contributor to $\left[\mathrm{A}_{4}+{ }^{6} \mathrm{Li}-\mathrm{H}\right]^{+}$than the monolithiated precursor. (For all peptides studied, the abundance of both the monolithiated and dilithiated precursors were the same.) This also was the general trend for all peptides investigated. The peptides YAGFM, YPFPG, YGGFL, and AAAAA all showed an ion 1 mass unit greater than the corresponding $\left[\mathrm{A}_{\mathrm{n}}+{ }^{6} \mathrm{Li}-\mathrm{H}\right]^{+}$ion in the precursor ion scans.

Figure $2 \mathrm{~b}$ indicates that the $\left[\mathrm{A}_{3}+{ }^{6} \mathrm{Li}-\mathrm{H}\right]^{+}$ion arises from the dilithiated molecular ion precursor as well as from the $\left[\mathrm{A}_{4}+{ }^{6} \mathrm{Li}-\mathrm{H}\right]^{+}$ion of $m / z 402$. Clearly missing is an ion at $m / z 256$ suggesting that a hydrogen radical is not lost from the third amino acid in the sequence. This is logical given the fact that glycine has no side chain and assuming Scheme II is the mechanism whereby these ions lose one hydrogen.

The case of lithiated leucine enkephalin is an interesting example in which great care is demanded in making structural assignments based on nominal masses of the ions. For instance, the precursor ion scan shown in Figure 2a indicates that an ion of $m / z$ 473 is also a precursor to $m / z 402$. Scheme III shows a proposed mechanism whereby the ion at $\mathrm{m} / \mathrm{z} 473$ might lead to a stable $Y$ type ion of $402 \mathrm{u}$. (The precursor at $m / z 517$ is still under investigation.) This fragmentation scheme suggests however that $m / z 402$ must be an unresolved doublet whereby two different mechanisms give rise to these isobars.

High resolution mass measurements of the ion at $m / z 402$ at $1: 20,000$ resolution did in fact show a doublet corresponding to $\mathrm{C}_{21} \mathrm{H}_{24} \mathrm{~N}_{4} \mathrm{O}_{4}{ }^{6} \mathrm{Li}=402.1955$ ( $+0.6 \mathrm{~mm}$ difference from theuretical), and $\mathrm{C}_{19} \mathrm{H}_{26} \mathrm{~N}_{4} \mathrm{O}_{5}{ }^{6} \mathrm{Li}_{2}=402.2206(0.0 \mathrm{mmu}$ difference from theoretical). The lower mass ion in the doublet is $\left[\mathrm{A}_{4}+{ }^{6} \mathrm{Li}-\mathrm{H}\right]^{+}$while the higher mass ion matches the elemental composition of the ion shown in Scheme III. Obviously, at unit mass resolution of the quadrupole mass analyzer, one cannot distinguish between these ions.

Fortunately, the remaining peptides investigated did not exhibit this overlap of $A_{n}$ and $Y_{n}$ ions. Evidence for this is shown in Figure 3 , in which the precursor ion scan for $m / z 416$ of YAGFM $\left(\left[\mathrm{A}_{4}+{ }^{6} \mathrm{Li}\right.\right.$ $-\mathrm{H}]^{+}$) is shown along with its exact mass measurement (measured at 1:20,000 with the double focusing portion $[\mathrm{BE}]$ of the instrument on the source-derived ions). At this resolution, the ion at $m / z 416$ appears as a singlet and is attributed to the $\left[\mathrm{A}_{4}+{ }^{6} \mathrm{Li}-\mathrm{H}\right]^{+}$ion. 


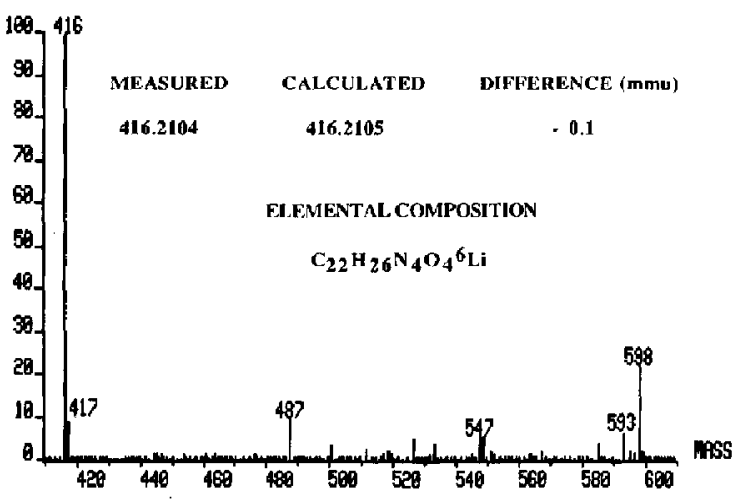

Figure 3. Precursor ion scan of $\left[\mathrm{A}_{4}+{ }^{6} \mathrm{Li}-\mathrm{H}\right]^{+}$from YAGFM. Inset indicates exact measurement of $m / z 416$, difference in millimass units from measured and calculated, and the corresponding elemental composition.

In this case, as with YPFPG, AAAAA, and YGGFL, the ion appearing at the mass corresponding to the $\left[\mathrm{A}_{\mathrm{n}}+{ }^{6} \mathrm{Li}\right]^{+}$ion is one of the precursors to $\left[\mathrm{A}_{\mathrm{n}}+{ }^{6} \mathrm{Li}\right.$ $-\mathrm{H}]^{+}$. Unfortunately, exact mass measurement of the $\left[\mathrm{A}_{\mathrm{n}}+{ }^{6} \mathrm{Li}\right]^{+}$ion for the peptides studied was not possible because the resolution required to resolve this ion from the ${ }^{13} \mathrm{C}$ isotope of the $\left[\mathrm{A}_{\mathrm{n}}+{ }^{6} \mathrm{Li}-\mathrm{H}\right]^{+}$ ion is $1: 90,000$.

At present, we can suggest no other logical mechanism whereby a hydrogen is removed to produce the $\left[\mathrm{A}_{\mathrm{n}}+{ }^{6} \mathrm{Li}-\mathrm{H}\right]^{+}$ion. Given the evidence presented here, it seems quite valid to entertain Scheme II as one mechanism for the formation of the $\left[\mathrm{A}_{\mathrm{n}}+{ }^{6} \mathrm{Li}-\right.$ $\mathrm{H}^{+}$ion. Obviously, this must be prefaced by saying that the above is true under the conditions of a low energy collision regime where multiple collisions are clearly taking place.

The mechanism shown in Scheme III raises an interesting issue, that is, is one or both lithiums coordinated to the internal carbonyls of leucine enkephalin (and perhaps of other peptides as well)? And if so, does this "activate" these carbonyls towards nucleophilic attack and/or does it initiate bond cleavage of the peptide backbone?

\section{Gly-Gly-Gly: Experimental and Theoretical Studies}

Modified neglect of differential overlap studies were undertaken in order to better determine where a lithium ion might coordinate to a peptide. Although the earliest work proposed coordination of sodium to the internal carbonyls of a peptide [1], recent mechanisms postulated for fragmentation of lithium-peptide adducts have indicated that the metal is coordinated to one of the terminal carboxy oxygens in the form of a lithiated zwitterion [4]. Evidence for both structures has been based on the formation of the $\left[\mathrm{B}_{n}+\mathrm{O}+\right.$ metal $+\mathrm{H}]^{+}$ion (Scheme IV) observed in both the metastable and the low and high energy collision spectra of ${ }^{18} \mathrm{O}$-labeled alkali metal-peptide adduct molecular ions $[1,4,6]$.

$\mathrm{Ab}$ initio studies of the amino acid glycine and its zwitterion (no metal ions present) have shown that in the gas phase, the zwitterion is less stable than the neutral form by approximately $125 \mathrm{~kJ} / \mathrm{mol}$ [12]. Similar $\mathrm{ab}$ initio scf studies of Gly-Gly-Gly showed the neutral form of the peptide to be more stable than the zwitterion by $501 \mathrm{~kJ} / \mathrm{mol}$ [9]. Given this evidence, and the fact that the lithium ion would prefer to be tricoordinate or tetracoordinate [13, and references therein], it is not unreasonable or unlikely for lithium to prefer internal coordination to the neutral form of Gly-GlyGly (Figure 4a) over the lithiated zwitterion (Figure 4b).

Collision-induced dissociation studies of the monolithiated molecular ion of Gly-Gly-Gly showed the characteristic $\left[\mathrm{B}_{\mathrm{n}}+\mathrm{O}^{6} \mathrm{Li}+\mathrm{H}\right]^{+}$ion reported previously, again reinforcing Scheme IV. However, MNDO calculations performed on various structural forms of the monolithiated Gly-Gly-Gly suggest that lithium is coordinated to the internal carbonyls of the neutral form of the molecule and is favored over structure $4 \mathrm{~b}$ by $305 \mathrm{~kJ} / \mathrm{mol}$. Figure 4a through $\mathrm{d}$ depicts some of the different structural isomers obtained from the MNDO calculations along with their respective heats of formation $\left(\Delta \mathrm{H}_{f}\right)$ (supplementary material which includes these four structures with cartesian coordi-<smiles>CCCCNC(=O)CNC(=O)CN</smiles><smiles>CN(CC12CC3OC(CC3O1)N2)C(=O)CN</smiles><smiles>CC1CNCCNC1=O</smiles><smiles>CCOC(=O)CNC(=O)C[NH3+]</smiles>

$m / z 138$

Scheme IV 


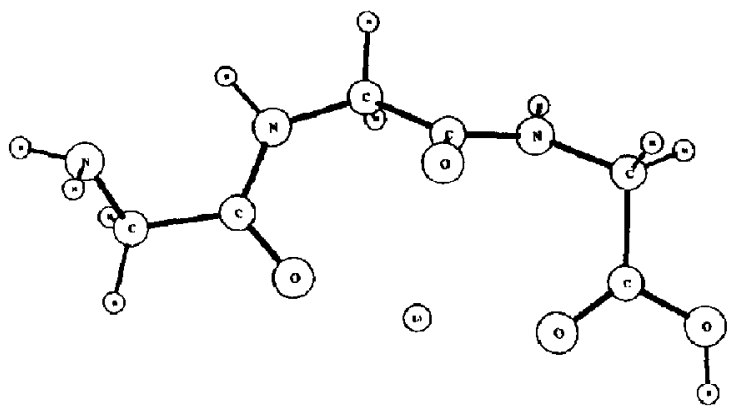

A<smiles>O=C(O)C(=O)C(=O)C(=O)C(=O)C(=O)C(=O)C(=O)C(=O)O</smiles>

$\mathbf{B}$
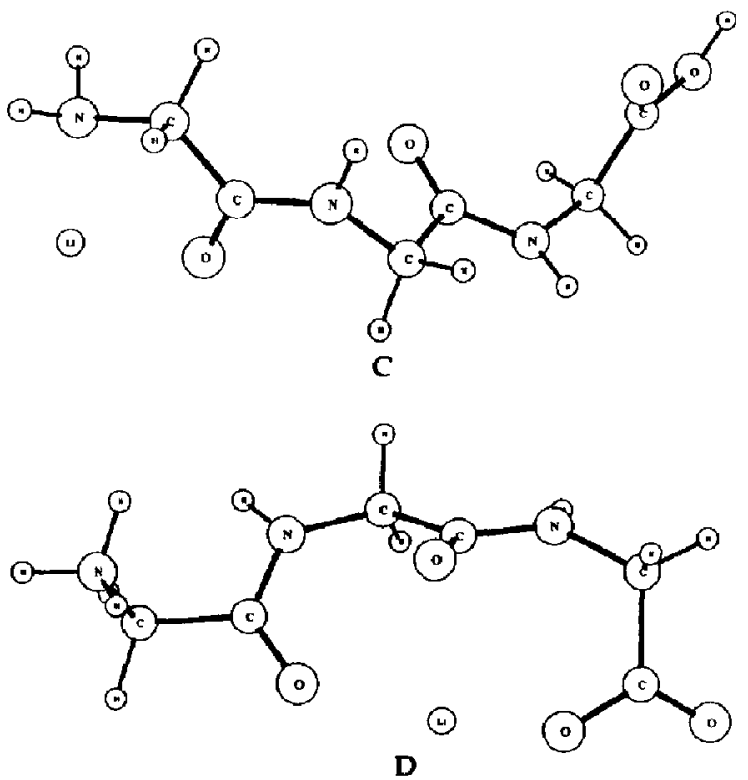

Figure 4. (a-d) show structures of lithiated Gly-Gly-Gly generated from MNDO calculations together with respective heats of formation $\left(\mathrm{H}_{\mathrm{f}}\right) . \Delta \mathrm{H}_{\mathrm{f}}=$ (a) $-333.75 \mathrm{~kJ} / \mathrm{mol}$; (b) $-28.80 \mathrm{~kJ} / \mathrm{mol}$; (c) $-265.09 \mathrm{~kJ} / \mathrm{mol}$; (d) $+10.99 \mathrm{~kJ} / \mathrm{mol}$.

nates and $\mathrm{z}$ matrices is available upon request). For all permutations minimized by the MNDO program, structure $4 \mathrm{~b}$ is one of the least favored.

As the collision energy for CID was on the order of $20 \mathrm{eV}$, it could be justifiably argued that the internal energy deposited upon collision would exceed the $\Delta \mathrm{H}_{\mathrm{f}}$ of $333 \mathrm{~kJ} / \mathrm{mol}$ for structure $4 \mathrm{a}$. Therefore, product ion spectra were obtained from the monolithiated molecular ion of Gly-Gly-Gly under unimolecular de- composition conditions and the results presented in Figure 5. The ions at $m / z 138$ and 81 assigned as the $\left[\mathrm{B}_{2}+\mathrm{O}^{6} \mathrm{Li}+\mathrm{H}\right]^{+}$and $\left[\mathrm{B}_{1}+\mathrm{O}^{6} \mathrm{Li}+\mathrm{H}\right]^{+}$ions, respectively, are still clearly present in the metastable ion spectra. Given the experimental and theoretical evidence presented, one must consider structure $4 \mathrm{~A}$ as an important, if not prevalent, precursor ion. It is highly likely that, at least for Gly-Gly-Gly, this form of the ion is the predominant one and that other mechanisms for the formation of the $\left[\mathrm{B}_{\mathrm{n}}+\mathrm{O}^{6} \mathrm{Li}+\right.$ $\mathrm{H}]^{+}$inn, such as those proposed earlier [1], must also be considered. Indeed, evidence has been presented that shows that protonated peptides also produce this comparable $B_{n}$ ion in the absence of alkali metals [14].

Although these data do not completely rule out structure $4 \mathrm{~b}$, it clearly demands that other structures be considered as well when postulating mechanisms for product ion formation. For instance, the structure shown in Figure $4 \mathrm{c}$ is only $41 \mathrm{~kJ} / \mathrm{mol}$ less stable than that shown in $4 \mathrm{a}$. Even under conditions of metastable ion decomposition, it would be very difficult to substantiate the existence of structure 4 a and deny that of $4 \mathrm{c}$ (approximately $0.3 \mathrm{eV}$ difference). Structures $4 \mathrm{c}$ and 4 a are of particular interest because they support experimental data that have shown that not only $A_{n}$ ions but also $C_{n}$ ions retain the Li atom [5]. Similarly, both $\mathrm{Na}$ and $\mathrm{K}$ atoms have also been retained in $A_{n}$ and $C_{n}$ ions observed previously [1]. It is more likely that the precursor ion population exists as a distribution of conformers and structural isomers, some more energetically favorable than others and that under low energy CID conditions different structural isomers give rise to the different ions observed. The most stable structure produced by FAB may not decompose during the time frame of the experiment and thus may be observed as the precursor in the product ion spectra.

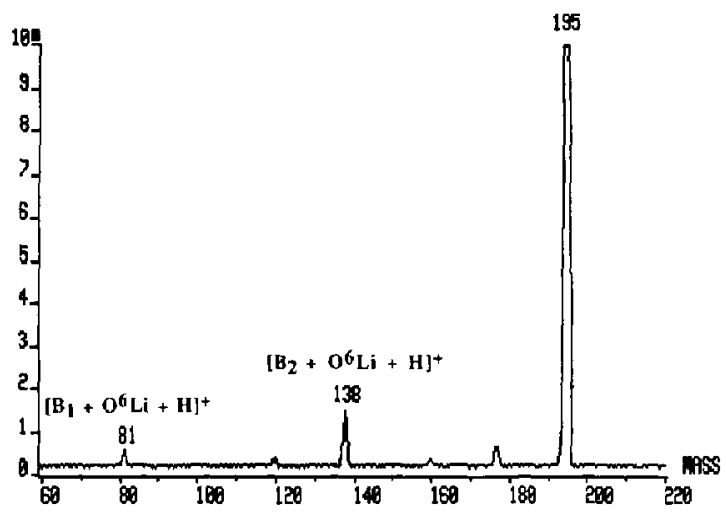

Figure 5. Spectrum generated from unimolecular decomposition of $[\mathrm{M}+\mathrm{Li}]^{+}$of Gly-Gly-Gly. Metastable precursor ions were transmitted into $q$ where their decompositions could be studied. 


\section{Conclusion}

Low energy CID of lithium-peptide adducts indicate that one of the precursors to the $\left[\mathrm{A}_{n}+\mathrm{Li}-\mathrm{H}\right]^{+}$ion is the $\left[A_{n}+L i\right]^{+}$ion. The merhanism of formation appears to be the same as reported previously for protonated peptides under high energy collisions. MNDO calculations of monolithiated Gly-Gly-Gly show that lithium prefers to coordinate to the three carbonyls of the neutral form of the peptide and is energetically more favorable than the lithiated zwitterion by $305 \mathrm{~kJ} / \mathrm{mol}$. In addition, at least one other structural isomer with lithium coordinated to the $\mathrm{N}$ terminus is only $41 \mathrm{~kJ} / \mathrm{mol}$ less stable. This suggests that more than one structural isomer makes up the precursor ion population. Therefore, different lithium-peptide adduct structures must be considered when formulating mechanisms of ion formation.

\section{Acknowledgments}

The authors wish to thank Mr. G. Bott for his assistance in maintenance and operation of the $\mathrm{ZAB2}-\mathrm{EQ}$ mass spectrometer. JAL gratefully acknowledges A. Streitwieser and R. Bergman for their helpful discussions, and Dr, R. Dixon is thanked for teaching JAL the mechanies and operation of the TektronixCAChe system. The ZAB2-EQ mass spectrometer was pur- chased with funds provided by the NIH (1-S10-RR03484-01), the NSF (CHE-8702669), and the University of California.

\section{References}

1. Tang, X.; Ens, W.; Standing, K. G.; Westmore, J. B. Anal. Chem. 1988, 60, 1791.

2. Russell, D. H.; McGlohon, E. S.; Mallis, L. M. Anal. Chem. 1988, 60, 1818 .

3. Renner, D.; Spitteller, G. Biomed. Enoiron. Mass Spectrom. $1988,15,75$.

4. Grese, R. P.; Cerny, R. L.; Gross, M. L. /. Am. Chem. Soc. 1989, 111, 2835.

5. Leary, J. A.; Williams, T. D.; Bott, G. Rapid Commun. Mass. Spec. 1989, 3, 192.

6. Thome, C. C.; Gaskell, S. J. Rapid Commun. Mass Spcc. $1989,3,217$.

7. Clark, T. A Handbook of Computational Chemistry; John Wiley: New York, 1985.

8. Meulemans, P. R.; Piret, P.; Van Meerssche, M. Acta. Cryst. $1971, B 27,1187$.

9. Wright, L. R.; Borkman, R, F. J. Phys. Chem. 1982, 86, 3956.

10. Johnson, R. S.; Martin, S. A.; Biemann, K. Int. J. Miass. Spectrom. Ion Proc. 1988, 86, 137.

11. Roepstorff, P.; Fohlman, J. Biomed. Mass. Spectrom. 1984, $11,601$.

12. Tse, Y.-C.; Newton, M. D.; Vishveshwara, S.; Pople, J. A. J. Am. Chem. Soc. 1978, 100, 4329.

13. Setzer, W. N.; Schleyer, P. V. R. Adv. Organomet. Chem. $1985,24,353$ (and references therein).

14. Thorne, G. C.; Ballard. K. D.; Gaskell, S. J. J. Am. Soc. Mass Spectrom. 1990, in press. 